\title{
EKSTRAKSI DAN KARAKTERISASI GELATIN KULIT IKAN BARONANG (Siganus canaliculatus) DENGAN METODE ENZIMATIS MENGGUNAKAN ENZIM BROMELIN
}

\section{(Extraction and Characterization of Gelatin from Baronang's (Siganus canaliculatus) Skin with Enzimatic Methode Using Bromelin Enzyme)}

\author{
Dian Haryati $^{\left.{ }^{1 *}\right)}$, Lulu Nadhifa ${ }^{1)}$, Humairah ${ }^{1)}$ dan Nurlaila Abdullah $^{1)}$ \\ ${ }^{1)}$ Prodi Ilmu dan Teknologi Pangan, Universitas Hasanuddin Jl. Perintis Kemrdekaan, KM 10, Makassar, \\ Indonesia \\ *) email Penulis Korespondensi: nur2511@ yahoo.com
}

\begin{abstract}
ABSTRAK
Gelatin adalah bahan makanan protein yang pada dasarnya murni, diperoleh dari denaturasi termal kolagen dari hewan. Gelatin dimanfaatkan sebagai bahan penstabil (stabilizer), pembentuk gel (gelling agent), pengikat (binder), pengental (thickener), pengemulsi (emulsifier), perekat (adhesive), whipping agent, serta pembungkus makanan yang bersifat edible coating. Kadar protein pada kulit ikan menentukan jumlah kolagen yang terkandung di dalam jaringan kulit, sehingga kulit ikan baronang memiliki peluang yang cukup besar sebagai sumber kolagen untuk dihidrolisis menjadi gelatin. Penelitian ini ditujukan untuk mengetahui karakteristik gelatin yang dihasilkan dari kulit ikan baronang dengan cara ekstraksi enzimatis dan untuk mengetahui perlakuan terbaik dari kombinasi konsentrasi enzim dengan lama ekstraksi. Pembuatan gelatine dilakukan dengan tahap hidrolisis menggunakan enzim bromelin pada konsesntrasi 1\%, 1,5\% dan 2\% dengan lama ekstraksi 2 jam, 4 jam dan 6 jam. Hasilnya, diperoleh gelatine dengan kadar air berkisar antara 3,13-5,83\%, kadar air berkisar antara 0,17-3,56\%, kadar abu 0,35 - 3,65\% dan kadar protein berkisar antara 91-94,72\%. Karakteristik kimia gelatine dari kulit ikan baronang memiliki rendemen hingga 6\%, kadar air $<6 \%$, kadar abu<4\% dan kadar protein mencapai 94\%. Perlakuan terbaik diperoleh pada konsentrasi enzim $1 \%$ dan ekstrakasi selama 4 jam dengan kadar protein sebesar $94,72 \%$.
\end{abstract}

Kata Kunci : enzim bromelin, gelatine, ikan baronang.

\section{ABSTRACT}

Basically, gelatin is pure protein food ingredient, obtained from thermal collagen denaturation from animals. Gelatin is used as a stabilizer, gelling agent, binder, thickener, emulsifier, adhesive, whipping agent, and food wrap which is edible coating. Protein levels in fish skin determine the amount of collagen contained in skin tissue, so the baronang fish skin has a considerable opportunity as a source of collagen to be hydrolyzed into gelatin. This study aimed to determine the characteristics of gelatin produced from baronang fish skin by enzymatic extraction and to determine the best treatment of a combination of enzyme concentrations with extraction time. Making gelatine was carried out by hydrolysis using bromelin enzyme at a concentration of 1\%, $1.5 \%$ and $2 \%$ with extraction time of 2 hours, 4 hours and 6 hours. The result, obtained gelatine with water content ranging from 3.13-5.83\%, the water content ranged from 0.17-3.56\%, ash content $0.35-3.65 \%$ and protein levels ranged from 91-94, 72\%. The chemical characteristics of gelatine from baronang fish skin have a yield of up to $6 \%$, water content $<6 \%$, ash content $<4 \%$ and protein content reaching $94 \%$. The best treatment was obtained at $1 \%$ enzyme concentration and extraction for 4 hours with a protein content of $94.72 \%$.

Keywords : Baronang fish, bromelin enzyme, gelatine. 


\section{PENDAhuluan}

Gelatin adalah bahan makanan protein yang pada dasarnya murni, diperoleh dari denaturasi termal kolagen dari hewan. Gelatin merupakan fraksi protein yang larut dalam air melalui tahap penguraian tersier, sekunder, dan sampai batas tertentu struktur primer dari kolagen. rsial kolagen yang berasal dari kulit, jaringan ikat putih dan tulang-tulang hewan. Gelatin termasuk polipeptida dengan berat molekul tinggi dan hidrokoloid penting, yang telah terbukti populer di masyarakat umum dan telah digunakan dalam berbagai produk makanan terutama karena sifat pembentuk gel dan kemampuannya meningkatkan viskositas.

Kolagen yang digunakan dalam pembuatan gelatin umumnya bersumber dari hewani seperti babi, sapi, dan ayam. Pada hewan, kolagen terdapat pada tulang, tulang rawan, kulit dan jaringan ikat. Gelatin dimanfaatkan sebagai bahan penstabil (stabilizer), pembentuk gel (gelling agent), pengikat (binder), pengental (thickener), pengemulsi (emulsifier), perekat (adhesive), whipping agent, serta pembungkus makanan yang bersifat edible coating. Gelatin digunakan dalam industri pembuatan jelly, industri daging, industri susu, dan supplement makanan. Dalam industri non pangan, gelatin banyak digunakan dalam industri farmasi dan kosmetik. Dalam industri farmasi, gelatin biasa digunakan dalam pembuatan kapsul lunak, cangkang kapsul dan tablet, sedangkan dalam industri kosmetik gelatin digunakan sebagai bahan kosmetik misalnya sampo dan sabun.

Luasnya penggunaan gelatin pada berbagai industry menyebabkan produksi gelatin semakin meningkat setiap tahunnya. Tahun 2010 produksi gelatin dunia mencapai 326.000 ton pertahun (See dkk, 2010). Diperkirakan sekitar 59\% gelatin yang diproduksi di seluruh dunia digunakan untuk industri makanan, $31 \%$ pada industri farmasi, $2 \%$ pada industri fotografi, dan sekitar $8 \%$ diaplikasikan dalam industri lainnya (Mohebi dan Shahbazi, 2017). Tercatat dalam Badan Pusat Statistika,
Indonesia masih mengimpor gelatin dari luar negeri berdasarkan data impor pada tahun 2013 sebesar $651.119 \mathrm{~kg}$, tahun 2014 sebesar $1.063 .111 \mathrm{~kg}$ dan pada tahun 2016 sebesar $1.354 .436 \mathrm{~kg}$. Menurut Karim (2009) gelatin impor yang dipasarkan di dunia (termasuk Indonesia) bahan bakunya diduga berasal dari kulit babi (46\%) maupun kulit sapi $(29,4 \%)$ dan tulang sapi $(23,1 \%)$ serta sumber lain $(1,5 \%)$. Selama ini kebutuhan gelatin Indonesia diimpor dari beberapa negara seperti Perancis, Jepang, India, Brazil, Jerman, Cina, Argentina dan Australia (BPS, 2015).

Penggunaan gelatin di Indonesia terus mengalami peningkatan, akan tetapi banyak hal yang mesti diwaspadai dalam hal ini misalnya isu kehalalan, penyakit mamalia dan flu burung. Dalam syariat islam, mengonsumsi bahan makanan dari babi atau memiliki kandungan babi merupakan makanan yang haram untuk dikonsumsi. Selain itu, penggunaan gelatin dari sapi maupun unggas juga memiliki resiko, misalnya penyakit sapi gila, antraks, serat flu burung yang dapat memperburuk kesehatan. Oleh karena itu pengembangan gelatin dari bahan yang lebih aman dan terjamin kehalalannya perlu dilakukan.

Salah satu solusinya yaitu pengembangan gelatin dari hasil laut. Bahan yang berpotensi sebagai bahan baku pengembangan gelatin yaitu ikan baronang. Ikan baronang (Siganus canaliculatus) adalah jenis ikan dengan jumlah hasil tanggap yang besar diperairan Sulawesi selatan. Ikan baronang memiliki kandungan gizi yang cukup tinggi. Bagian tubuh ikan baronang yang dapat dimanfaatkan sebagai bahan pembuatan gelatin yaitu bagian kulit. Menurut Wahyuningtyas (2015) kulit ikan baronang memiliki kandungan protein sebesar $15,98 \%$. Kadar protein pada kulit ikan menentukan jumlah kolagen yang terkandung di dalam jaringan kulit, sehingga kulit ikan baronang memiliki peluang yang cukup besar sebagai sumber kolagen untuk dihidrolisis menjadi gelatin.

Kebutuhan gelatin yang terus mengalami peningkatan setiap tahunnya. 
Sebagian besar kebutuhan gelatin dipenuhi oleh gelatin yang berasal dari babi. Dalam syariat islam mengonsumsi makanan dengan kandungan babi adalah haram. Oleh karena itu diperlukan alternatif gelatin untuk memenuhi kebutuhan gelatin yang terjamin kehalalannya. Gelatin yang dapat digunakan sebagai alternatif gelatin dari kulit ikan baronang. Oleh karena itu, penelitian ini ditujukan untuk mengetahui karakteristik gelatin yang dihasilkan dari kulit ikan baronang dengan cara ekstraksi enzimatis dan untuk mengetahui perlakuan terbaik dari kombinasi konsentrasi enzim dengan lama ekstraksi.

\section{METODOLOGI PENELITIAN}

\subsection{Alat}

Alat yang digunakan dalam penelitian ini untuk prosedur preparasi dan ektraksi gelatin, alat yang digunakan yaitu baskom, pisau, gelas ukur, gelas kimia, stopwatch, erlenmeyer, termometer, saringan, oven, blender, waterbath shaker, HPLC dan timbangan analitik. Dan untuk prosedur karaktertisasi gelatin hasil ektraksi, alat yang digunakan yaitu $\mathrm{pH}$ meter, tanur, cawan porselen, alat titrasi dan alat kjeldahl.

\subsection{Bahan}

Bahan yang digunakan dalam penelitian ini adalah kulit ikan baronang, aquades, enzim beromelin dari nanas, kertas $\mathrm{pH}$, Na2SO4, CuSO4, H2SO4, $\mathrm{NaOH}, \mathrm{HCl}$, H3BO3, metal merah, dan metal biru.

\subsection{Prosedur Penelitian}

Prosedur penelitian meliputi preparasi sampel, hidrolisis dengan tiga jenis konsentrasi enzim yaitu $1 \%, 1,5 \%$ dan $2 \%$, ekstraksi yang divriasikan yaitu 2, 4 dan 6 jam, pengujian kadar air, kadar abu, kadar protein dan komposisi asam amino.

\subsubsection{Preparasi dan Pembuatan Gelatin dari Kulit Ikan Baronang}

Kulit ikan baronang dibersihkan dari sisa daging dan kotoran lainnya, kulit ikan baronang kemudian dipotong dengan ukuran $1 \times 2 \mathrm{~cm}$ dan dicuci dengan aquades kemududian dimasak selama 2 menit. Tahapan selanjutnya yaitu hidrolisis kulit ikan dengan menggunakan enzim protease berupa enzim bromelin dengan perlakuan konsentrasi $(1 \%, 1,5 \%$, dan $2 \%)$ selama 2 jam. Setelah proses hidrolisis selesai kulit ikan kemudian dicuci dengan aquades sampai $\mathrm{pH}$ netral. Kulit hasil hidrolisis kemudian diekstraksi dengan penambahan aquades dengan perbandingan 1:3 (Hasil hidrolisis : Aquades) dalam waterbath shaker pada suhu $50^{\circ} \mathrm{C}$ selama 2 jam, 4 jam dan 6 jam. Hasil ekstraksi disaring, hasil penyaringan dikeringkan dalam oven pada suhu $45-50^{\circ} \mathrm{C}$ selama 24 jam. Lembaran gelatin yang diperoleh kemudian digiling sehingga menghasilkan bubuk gelatin dan siap untuk digunakan untuk tahapan selanjutnya.

\subsubsection{Pengujian Kadar Air}

Cawan porselen dikeringkan pada suhu $105^{\circ} \mathrm{C}$ selama 1 jam. Kemudian didinginkan dan ditimbang. Cawan yang telah berisi sampel dimasukkan ke dalam oven bersuhu $105^{\circ} \mathrm{C}$ sampai beratnya konstan (AOAC, 1995)

\subsubsection{Pengujian Kadar Abu (AOAC, 1995)}

Contoh yang telah diuapkan airnya dimasukkan ke dalam tanur bersuhu 6000C, sebelumnya berat cawan kering dan berat contoh telah diketahui. Proses penguapan dilakukan sampai semua bahan berubah warna menjadi abu-abu, kemudian contoh ditimbang.

\subsubsection{Perhitungan Rendemen}

Rendemen adalah berat ekstrak dibagi dengan berat sampe dan dikali $100 \%$. Perhitungan rendemen perlu dilakukan untuk mengetahui efektivitas dari enzim. Semakin tinggi nilai rendemen yang dihasilkan maka semakin rendah mutu produk yang didapatkan. 


\subsubsection{Komposisi Asam Amino dengan HPLC (Muchtadi dkk, 1992)}

Sebanyak 0.2 gram sampel disiapkan dalam tabung reaksi tertutup dan ditambahkan sebanyak $5 \mathrm{ml} \mathrm{HCl} 6 \mathrm{~N}$. Sampel dimasukkan dalam oven dengan suhu $100 \circ$ C selama 18-24 jam. Selanjutnya sampel disaring dengan kertas saring whatman 40. Hasil hidrolisis dipipet sebanyak $10 \mathrm{ml}$ dan dimasukkan ke dalam tabung reaksi. Kemudian ditambahkan $30 \mathrm{ml}$ larutan pengering, lalu dikeringkan dengan pompa vakum bertekanan 50 torr. Sampel yang telah dikeringkan ditambahkan larutan derivat sebanyak $30 \mathrm{ml}$ dan dibiarkan selama \pm 20 menit. Sampel selanjutnya diencerkan dengan $200 \mathrm{ml}$ larutan pengencer natrium asetat $1 \mathrm{M}$. Sampel siap dianalisis dengan menggunakan HPLC Waters Associates.

\section{HASIL DAN PEMBAHASAN}

\subsection{Rendemen}

Rendemen adalah salah satu parameter penting dalam proses pembuatan gelatin yang digunakan untuk menentukan efektivitas metode yang digunakan. Tingkat efisien dan efektifnya proses ekstraksi bahan baku yang digunakan dalam pembuatan gelatin dapat dilihat dari nilai rendemen yang dihasilkan. Semakin besar rendemen yang dihasilkan maka semakin efisien perlakuan metode yang digunakan. Rendemen dihitung dengan perbandingan berat gelatin yang dihasilkan dan berat bahan baku yang digunakan. Adapun hasil rendmen yang diperoleh dalam penelitian ini dapat dilihat pada tabel dan grafik dibawah ini.

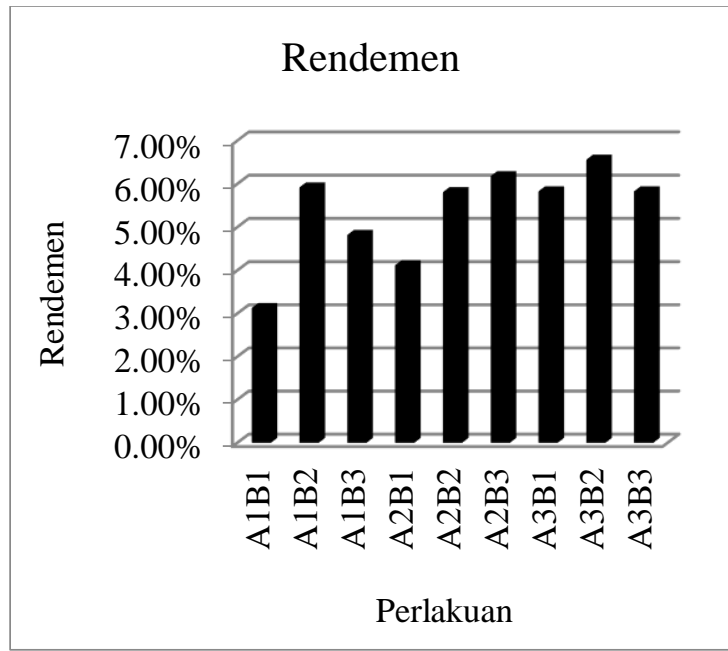

Gambar 01. Grafik Hasil Perhitungan Rendemen Gelatin Kulit Ikan Baronang

Keterangan :

A1B1 : Enzim 1\%, Lama ekstraksi 2 jam A1B2 : Enzim 1\%, Lama ekstraksi 4 jam A1B3 : Enzim 1\%, Lama ekstraksi 6 jam A2B1 : Enzim 1,5\%, Lama ekstraksi 2 jam A2B2 : Enzim 1,5\%, Lama ekstraksi 4 jam A2B3 : Enzim 1,5\%, Lama ekstraksi 6 jam A3B 1 : Enzim 2\%, Lama ekstraksi 2 jam A3B2 : Enzim 2\%, Lama ekstraksi 4 jam A3B3 : Enzim 2\%, Lama ekstraksi 6 jam

Metode perlakuan yang digunakan dalam penelitian ini yaitu perlakuan konsentrasi enzim dan lama waktu ekstraksi. Menurut Ward \& Courts (1977) konversi kolagen menjadi gelatin dipengaruhi oleh suhu, waktu pemanasan dan $\mathrm{pH}$. Semakin lama waktu ekstraksi, rendemen semakin meningkat. Hal ini diduga karena jumlah ion $\mathrm{H}+$ yang menghidrolisis kolagen lebih banyak, sementara semakin lama ekstraksi menyebabkan kolagen terurai lebih banyak menjadi gelatin. Ikatan hidrogen dalam tropokolagen didenaturasi oleh molekul $\mathrm{H}_{2} \mathrm{O}$. Tahap ekstraksi menyebabkan molekul triple-helix kehilangan stabilitasnya dan akhirnya terurai menjadi rantai tunggal gelatin. Ikatan hidrogen dalam tropokolagen ini didenaturasi oleh molekul $\mathrm{H}_{2} \mathrm{O}$. Tahap ekstraksi ini menyebabkan molekul triplehelix kehilangan stabilitasnya dan akhirnya terurai menjadi rantai tunggal gelatin. Selain 
itu, konsetrasi enzim juga mempengaruhi banyaknya rendemen yang dihasilkan, semakin tinggi konsentrasi enzim yang digunakan semakin banyak ikatan peptide yang dihidrolisis. Rendemen yang dihasilkan dari reaksi antara substrat dan enzim dipengaruhi oleh kondisi dari konsetrasi enzim. Pada keadaaan konsetrasi enzim meningkat sedangkan konsetrasi substrat tetap, konsetrasi atau jumlah molekul enzim lebih rendah dibandingkan jumlah molekul substrat yang akan dikatalis, sehingga produk yang dihasilkan akan sebanding dengan jumlah substrat yang diubah oleh enzim menjadi prosuk. Bila jumlah enzim meningkta maka semakin banyak substrat yang akan diubah menjadi produk sehingga suatu ketika jumlah enzim berlebih namun substrat habis. Akibatnya penambahan enzim tidak dapat mengubah grafik reaksi terhadap konsetrasi enzim (Adhiyanto et al, 2006). Hasil diatas menujukkan adanya perbedaan rendemen yang dihasilkan setiap perlakuan, namun pada konstrasi dan waktu tertentu rendemen yang dihasilkan tidak menunjukkan garis lurus. Sehingga dapat dikatakan bahwa pada keadaan tersebut substrat telah habis dikatalis sehingga grafik yang diperoleh tidak menunjukkan peningkatan hasil rendemen. Hasil rendemen tertinggi yang diperoleh yaitu $6,56 \%$ dengan perlakuan konsentrasi enzim 2\% dan lama ekstraksi 4 jam.

\subsection{Kadar Air}

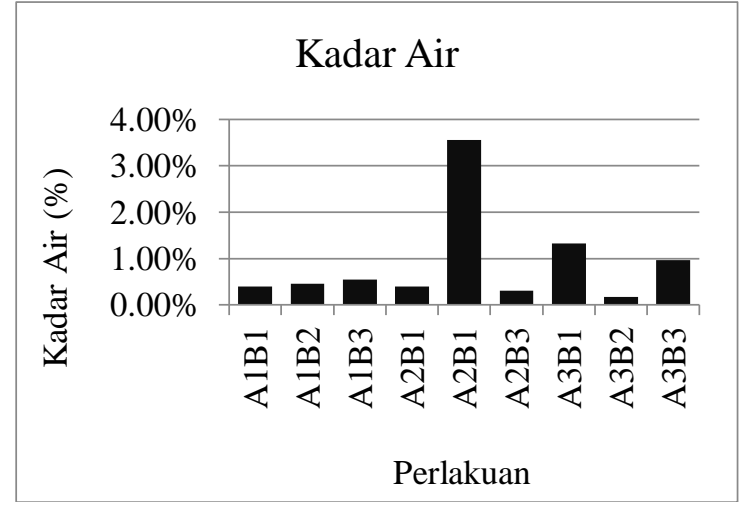

Gambar 02. Grafik Hasil Perhitungan Kadar Air Gelatin Kulit Ikan Baronang
Keterangan :

A1B1 : Enzim 1\%, Lama ekstraksi 2 jam A1B2 : Enzim 1\%, Lama ekstraksi 4 jam A1B3 : Enzim 1\%, Lama ekstraksi 6 jam A2B1 : Enzim 1,5\%, Lama ekstraksi 2 jam A2B2 : Enzim 1,5\%, Lama ekstraksi 4 jam A2B3 : Enzim 1,5\%, Lama ekstraksi 6 jam A3B1 : Enzim 2\%, Lama ekstraksi 2 jam A3B2 : Enzim 2\%, Lama ekstraksi 4 jam A3B3 : Enzim 2\%, Lama ekstraksi 6 jam

Kadar air adalah kandungan air bahan yang dapat dinyatakan berdasarkan berat basah dan berat kering (Syarief dan Halid, 1993). Kadar air dapat mempengaruhi penampakan tekstur, cita rasa serta bahan pangan, kadar air gelatin akan berpengaruh terhadap daya simpan karena erat kaitannya dengan aktivitas metabolisme yang terjadi selama gelatin tersebut disimpan seperti aktivitas enzim, aktivitas mikroba dan aktivitas kimiawi, yaitu terjadinya ketengikan dan reaksi-reaksi non enzimatik sehingga menimbulkan perubahan sifat-sifat organoleptik dan nilai mutunya (Rachmania, 2013).Hasil pengukuran kadar air gelatin menunjukkan bahwa kadar air gelatin kulit ikan baronang yang diperoleh berkisar antara $0.17 \% \%-3.56 \%$ sehingga masih memenuhi kisaran standar mutu gelatin yaitu maksimum 16\% (SNI 06-3735, 1995). Kadar air tertinggi sebesar $3.56 \%$ diperoleh pada perlakuan konsentrasi enzim 1,5\% dan lama inkubasi 2 jam, sedangkan kadar air terendah sebesar $0.17 \%$ diperoleh pada perlakuankonsentrasi enzim $2 \%$ dan lama inkubasi 4 jam. Kadar air gelatin yang rendah dari kulit ikan baronang diduga karena pengaruh pengeringan pada proses pembuatan gelatin kulit ikan baronang ini mengunakan oven suhu $45-50^{\circ} \mathrm{C}$ berbeda dengan gelatin komersial pada gelatin komersial biasanya menggunakan freeze dryer. Amiruldin (2007) menyatakan bahwa, kadar air yang rendah akan mempengaruhi mutu gelatin terutama pada ketengikan gelatin dan warna yang kurang cerah. 


\subsection{Kadar Abu}

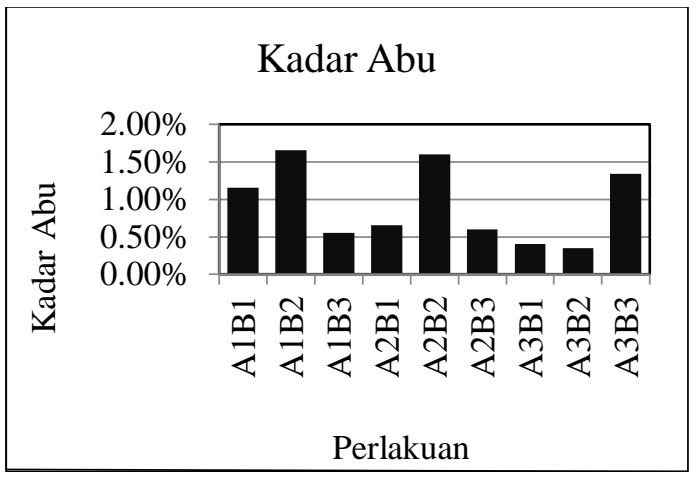

Gambar 03. Grafik Hasil Perhitungan Kadar Abu Gelatin Kulit Ikan Baronang

Keterangan :

A1B1 : Enzim 1\%, Lama ekstraksi 2 jam A1B2 : Enzim 1\%, Lama ekstraksi 4 jam A1B3 : Enzim 1\%, Lama ekstraksi 6 jam A2B1 : Enzim 1,5\%, Lama ekstraksi 2 jam A2B2 : Enzim 1,5\%, Lama ekstraksi 4 jam A2B3 : Enzim 1,5\%, Lama ekstraksi 6 jam A3B1 : Enzim 2\%, Lama ekstraksi 2 jam A3B2 : Enzim 2\%, Lama ekstraksi 4 jam A3B3 : Enzim 2\%, Lama ekstraksi 6 jam

Abu merupakan residu anorganik dari pembakaran bahan-bahan organik dan biasanya komponen-komponen tersebut terdiri dari kalsium, natrium, besi, magnesium, dan mangan. Abu yang terbentuk berwarna putih abu-abu, berpartikel halus dan mudah dilarutkan. Tujuan dari analisa kadar abu adalah untuk mengetahui secara umum kandungan mineral yang terdapat dalam bahan. Menurut Apriyantonoet al., (1989) menyatakan bahwa nilai kadar abu suatu bahan pangan menunjukkan besarnya jumlah mineral yang terkandung dalam bahan pangan tersebut.

Hasil pengukuran kadar abu gelatin menunjukkan bahwa kadar abu gelatin kulit ikan baronang yang diperoleh berkisar antara $0.35 \%-1.65 \%$. Nilai kadar abu gelatin kulit ikan baronang tersebut memenuhi standar SNI 06-3735, 1995 yaitu sebesar maksimum $3.25 \%$. Kadar abu tertinggi sebesar $1.65 \%$ diperoleh pada perlakuan konsentrasi enzim $1 \%$ dan lama inkubasi 4 jam, sedangkan kadar air terendah sebesar $0.35 \%$ diperoleh pada perlakuan konsentrasi enzim 2\% dan lama inkubasi 4 jam. Penentuan kadar abu dimaksudkan untuk mengetahui kandungan komponen yang tidak mudah menguap (komponen anorganik atau garam mineral) yang tetap tinggal pada pembakaran dan pemijaran senyawa organik (Nurilmala, 2006). Semakin rendah kadar abu suatu bahan, maka semakin tinggi kemurniannya. Tinggi rendahnya kadar abu suatu bahan antara lain disebabkan oleh kandungan mineral yang berbeda pada sumber bahan baku dan juga dapat dipengaruhi oleh proses demineralisasi pada saat pembuatan (Sudarmaji, 1995).

\subsection{Kadar Protein}

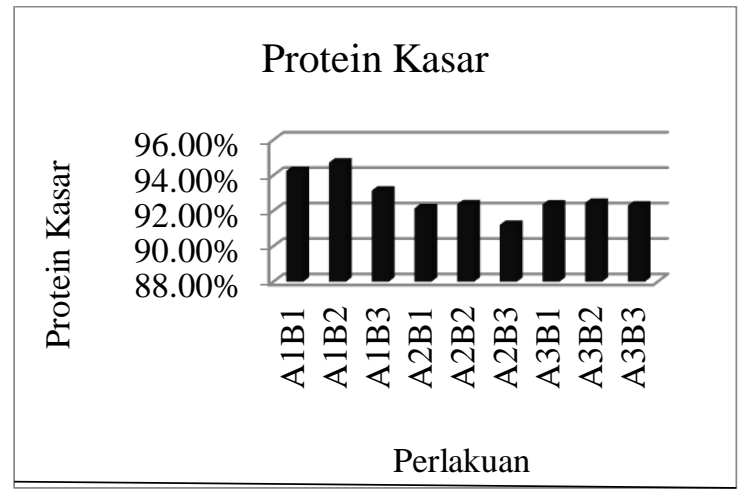

Gambar 04. Grafik Hasil Analisa Kadar Protein Kasar Gelatin Kulit Ikan Baronang

Keterangan :

A1B1 : Enzim 1\%, Lama ekstraksi 2 jam A1B2 : Enzim 1\%, Lama ekstraksi 4 jam A1B3 : Enzim 1\%, Lama ekstraksi 6 jam A2B1 : Enzim 1,5\%, Lama ekstraksi 2 jam A2B2 : Enzim 1,5\%, Lama ekstraksi 4 jam A2B3 : Enzim 1,5\%, Lama ekstraksi 6 jam A3B 1 : Enzim 2\%, Lama ekstraksi 2 jam A3B2 : Enzim 2\%, Lama ekstraksi 4 jam A3B3 : Enzim 2\%, Lama ekstraksi 6 jam

Protein pada gelatin termasuk salah satu parameter yang menentukan kualitas gelatin yang dibuat. Berdasarkan hasil uji protein kasar, kadar protein gelatin dari kulit ikan baronang berkisar antara 92\% hingga 94\%. Kadar protein tertinggi terdapat pada perlakuan A1B2 yaitu 94,72\% sedangkan kadar protein terendah pada perlakuan A2B3 
yaitu $91,21 \%$. Kadr protein ini masih cukup tinggi dibandingkan dengan kadar protein dari berbagai sumber seperti kulit ikan tenggiri sebesar 23,13\% (Gunawan, dkk. 2017), kulit ikan tongkol sebesar 24,63\% (Komala, 2015),kulit ikan ekor kuning sebesar 17,87\% (Astiana, dkk. 2016) dan kulit ikan hiu sebesar 27,73\% (Herna, dkk. 2013). Sementara itu, kadar protein dari ikan baronang sedikit lebih rendah dari gelatin kulit ikan patin. Dibuktikan oleh penelitian Nasution, dkk (2018) yang membuat gelatin dari kulit ikan patin dengan protein sebesar $97,71 \%$. Kadar protein yang berbeda-beda selalu berkaitan erat dengan perlakuan yang diberikan. Kensentrasi enzim sebanyak $1 \%$ dengan lama ekstraksi 4 jam memberikan kadar protein tertinggi. Pengujian kadar protein dimaksudkan untuk melihat kemampuan gelatin dalam membentuk gel. Semakin tinggi kadar proteinnya, maka kemampuan untuk membentuk gel serta viskositas semakin meningkat. Berdasarkan Santoso (2015), protein pada gelatin sangat berpengaruh terhadap pembentukan gelnya.

\section{KESIMPULAN}

Karakteristik kimia gelatine dari kulit ikan baronang memiliki rendemen hingga $6 \%$, kadar air $<6 \%$, kadar abu<4\% dan kadar protein mencapai $94 \%$. Perlakuan terbaik diperoleh pada konsentrasi enzim $1 \%$ dan ekstrakasi selama 4 jam dengan kadar protein sebesar $94,72 \%$.

\section{DAFTAR PUSTAKA}

Adhiyanto, C. (2006). Pemanfaatan Tentang Enzim dan Manfaatnya dalam Bidang Biomedik. UIN Jakarta Press : Jakarta.

Astiana I, Nurjanah, Nurhayati T. (2016). Karakteristik kolagen larut asam dari kulit ikan ekor kuning. Jurnal Pengolahan Hasil Perikanan Indonesia, 19(1), $79-93$.

Fahrul. (2005). Kajian Ekstraksi Gelatin Dari Kulit Ikan Tuna (Thunnus alalunga) dan Karakteristiknya sebagai
Bahan Baku Industri Farmasi. Sekolah Pascasarjana Institut Pertanian Bogor. Bogor.

Gunawan, F., Suptijah, P., dan Uju. (2017). Ekstraksi dan Karakterisasi Gelatin Kulit Ikan Tenggiri (Scomeromorus commersonii) dari Provinsi Kepulauan Bangka Belitung. Jurnal Pengolahan Hasil Perikanan Indonesia, 20 (3), 568 $-581$.

Hema GS, Shyni K, Mathew S, Anandan R, Ninan G. (2013). A simple method for isolation of fish skin collagenbiochemical characterization of skin collgagen extracted from albacore tuna (Thunnus alalunga), dog shark (Scoliodon sorrakowah), and rohu (Labeo rohita). Annals of Biological Research. 4(1): 271- 278.

Nasution, AY., Harmita., dan Harahap, Y. (2018). Karakterisasi Gelatin Hasil Ekstraksi dari Kulit Ikan Patin (Pangasius hypophthalmus) dengan Proses Asam dan Basa. Pharmaceutical Science and Research, 5 (3), 142-151.

Santoso, C., Surti, T., dan Sumardianto. Perbedaan Penggunaan Konsentrasi Larutan Asam Sitrat Dalam Pembuatan Gelatin Tulang Rawan Ikan Pari Mondol (Himantura gerrardi). Jurnal Pengolahan dan Bioteknologi Hasil Perikanan, 4 (2), 106 - 114.

Sudarmaji,S., (1995). Prosedur Analisa Bahan Makanan Pertanian, Liberty, Yogyakarta.

Ward, A.G. \& Courts, A. (1977). The Science and Technology of Gelatin. New York: Academic Press. 